\title{
Legal aspects regarding the increase of the capital of a joint-stock company and a limited liability company
}

\author{
Andreea STOICAN \\ Bucharest University of Economic Studies, Bucharest, Romania \\ andreea.stoican@drept.ase.ro
}

\begin{abstract}
In the business world, certain needs of the company may impose the necessity to increase its capital. These needs may consist either in the desire of the partners to develop the company's activity, either to remove certain financial difficulties. The modalities and procedures for increasing the capital are regulated by Law no. 31/1990 on companies, having various particularities and immediate effects.

The current paper, therefore, aims in presenting these methods and their particularities, both from a theoretical and practical point of view, in a comparative way, for the joint-stock companies and the limited liability companies, as the most frequently existing types of company in Romanian law.
\end{abstract}

Keywords: subscribed capital, paid-up capital, nominal value of shares, legal reserves.

In the business world, certain needs of the company may impose the necessity to increase its capital. These needs may consist either in the desire of the partners to develop the company's activity, either to remove certain financial difficulties. The modalities and procedures for increasing the capital are regulated by Law no. 31/1990 on companies, having various particularities and immediate effects.

The current paper, therefore, aims in presenting these methods and their particularities, both from a theoretical and practical point of view, in a comparative way, for the joint-stock companies and the limited liability companies, as the most frequently existing types of company in Romanian law.

The legal capital, part of a company's patrimony, represents the contribution in money or kind brought by the associates of the company, at the date of its establishment (Dumitru, 2019, p. 167).

Increasing the legal capital is beneficial if we consider the ways in which this contribution can be used. The sums of money that represent the contribution to the establishment or increase of the legal capital can be used in the daily activity of the company, for the purchase of goods or services, for the payment of salaries or taxes and duties. Also, from a certain level of the legal capital, a company can opt for the payment of the profit tax.

The increase of the legal capital determines the change of the constitutive act of the company in order to reflect the new contributions of the associates and the highlighting of the new participation titles issued in exchange for these contributions (Gheorghe, 2020, p. 492).

According to article 210 from Law no. 31/1990 on companies, there are multiple methods for the increase of the legal capital, respectively: by issuing new contributions; including the reserves; including the benefits and the issue premiums or by compensation of some certain and liquid debts.

The activity of companies, irrespective of their object of activity, is regulated through law no. 31/1990. This normative act also applies to companies destined for commercial activity with foreign participation (Lupulescu, 2016, p. 125). The usefulness of increasing the legal capital can be determined to develop the activity of the company or to remove some financial difficulties or the need to revalue the company's assets. In addition, the Law no. 31/1990, through art. 10 also

DOI: $10.2478 /$ picbe-2021-0093

(C) 2021 A. Stoican, published by Sciendo.

This work is licensed under the Creative Commons Attribution 4.0 License. 
provides that the increase of the legal capital of the company may be required by law when it changes the minimum value (Cărpenaru, 2012, p. 241).

Regarding the contributions of the associates to the legal capital, the legal restrictions brought to the will of the associates in this matter are common to the matter of the setting-up of the company. The restrictions over the contributions in receivables and work benefits concerning the joint-stock companies set up by public subscription or limited liability companies, incidental to the incorporation of companies, remain applicable to any subsequent capital increase. The legal rules, in fact, concern any contribution, being applicable also to the incorporation and changes brought to the companies (Tănăsică, 2017, p. 41).

The increase of the legal capital involves two main stages: the adoption of the decision for the increase of the legal capital and the development of the actual increase procedure of legal capital. The legal capital can also be increased through certain operations, without new contributions.

According to art. 219 from Law no. 31/1990, the decision of the general meeting on the increase of the legal capital shall take effect only in so far as it is carried out within one year from the date of its adoption. If the proposed capital increase is not fully subscribed, the capital will be increased in the amount of subscriptions received only if the terms of issue provide for this possibility.

As seen, the first method of increasing the legal capital is through issuing new contributions, such as either new shares or the increase of the nominal value of the already existing ones. However, in case of companies by shares, the increase of the capital cannot operate if the previous issue was not completely paid for.

Also, in case of the increase of the capital through raising the nominal value of the already existing shares or social parts, it can only operate if the new contributions are exclusively brought in money or in assets by the already existing shareholders or associates (Nemes, 2018, p. 178).

The second method of increasing the capital refers to the inclusion of reserves, with the exception of the legal reserves.

According to art. 210 paragraph 2 of Law 31/1990 on companies, republished, with subsequent amendments, the legal capital may be increased by incorporating reserves, except for the legal reserves, as well as the benefits or issue premiums, or by offsetting liquid and due receivables on the company with its actions. Also, according to art. 210 paragraph 3 of the law, the favorable differences from the revaluation will be included in the reserves, but they cannot increase the legal capital.

However, this procedure also implies certain particularities from an accounting point of view, as regulations must follow these legal provisions, respectively for the increase of the legal capital from other reserves, the accounting formula is 1068 "Other reserves" = 1012 "Paid subscribed capital". It is not possible to increase the legal capital from the legal reserve.

In addition, also from a fiscal point of view, according to art. 23 of the Fiscal Code, when calculating the tax result, the following income is non-taxable, respectively:

- the value of new equity securities or the amounts representing the increase in the nominal value of existing equity securities, registered as a result of the incorporation of reserves, benefits or issue premiums to the legal entities in which the equity securities are held. They are taxable on the date of the transfer, free transfer, withdrawal of the legal capital or liquidation of the legal entity in which the shares are held - income from cancellation, recovery, including re-invoicing of expenses for which no deduction was granted, income from reduction or cancellation of provisions for which no deduction was granted, income from restitution or cancellation of interest and/or 
penalties for which no deduction was granted, and income representing the cancellation of the reserve registered as a result of the participation in kind in the capital of other legal entities or as a result of the increase of the legal capital in the legal person in which the equity securities are held.

From a legal point of view, however, in the matter of fiscality, the importance of the principle of legal certainty cannot be ignored, as it also needs to be linked to the principle of the protection of the legitimate taxpayers' expectations. This implies the existence of very clear rules that shouldn't lead to any interpretations, as taxpayers need to not only understand, but also anticipate any burden of fiscal nature that may occur (Chirieac, 2020, p. 4).

In what would have implied the legal reserves, which cannot be used for the increase of the legal capital, they imply that at least $5 \%$ of the company's profit will be taken over each year for the formation of the reserve fund, until it reaches at least one fifth of the legal capital. According to art. 183 of the company law, if the reserve fund, after its establishment, has decreased due to any reason, it will be completed. Also, the surplus obtained by selling the shares at a price higher than their nominal value, if this surplus is not used to pay the issue expenses or intended for depreciation, is also included in the reserve fund, even if it has reached the amount provided in the law for the legal reserves. The founders will participate in the profit, if this fact is provided in the constitutive act or, in the absence of such provisions, it has been approved by the extraordinary general assembly. However, in all cases, the conditions of participation will be established by the general meeting, for each financial year.

The third method for increasing the legal capital is by including the benefits and the issue premiums.

The issue premium is the difference between the issue value and the nominal value of the

shares, which must be borne by the new shareholders. It is intended to cover issuance costs and diminishing the intrinsic value of old shares. The increase of the legal capital with the issue premium is not mandatory, but an option of the general assembly. The issue premium is a contribution supplement, but it is not incorporated in the legal capital, but is recorded in a reserve account of which the company disposes of according to its interests. It must be paid in full on the date of the subscription of the shares. Increase in legal capital by the method of incorporating the profit or of the issue premiums is realized, as in the case of the method of incorporating reserves, through an accounting operation between the liability or passive accounts (Tănășică, 2017, p. 45).

The fourth and last method of increasing the legal capital is through compensation of some certain and liquid debts of third parties with its own shares.

The increase of the legal capital through the reserves, the benefits and the issue premiums or by compensation of some certain and liquid debts does not imply or represent new contributions of the shareholders or third parties. The shares issued as a consequence of such an increase are gratuitously distributed to the already existing shareholders (Piperea, 2020, p. 451).

However, additionally, it is essential to also mention the increase of the legal capital in the case of the authorized capital, operation regulated by art. $220^{1}$ of Law no. 31/1990.

As such, the legislator understands to regulate the authorized capital as the maximum nominal value, established by the constitutive act or the decision of the general meeting, the amount up to which the capital may be increased, based on the decision of the board of directors or the directorate, in a joint-stock company.

Through the constitutive act, the board of directors, respectively the directorate, may be authorized, in a certain period, which may not exceed 5 years from the date of incorporation of the company, to increase the subscribed legal capital to a certain nominal value (named authorized capital), by issuing new shares in exchange for contributions. Such authorization may also be 
granted by the general meeting of shareholders, by an amendment of the articles of association, for a certain period, which may not exceed 5 years from the date of registration of the amendment. The articles of association may increase the quorum requirements for such an amendment.

However, the nominal value of the authorized capital may not exceed half of the subscribed legal capital, existing at the time of authorization.

By the granted approval, the board of directors or the directorate, respectively, may also be given the power to decide to restrict or lift the pre-emptive right of existing shareholders. This authorization is granted to the board of directors, respectively to the directorate, by the general assembly, under the conditions of quorum of three quarters of the subscribed legal capital and the decision will be taken with the majority of votes of the present shareholders. The decision of the board of directors, respectively of the directorate, regarding the restriction or lifting of the right of preference is submitted to the trade register office, for mention in the trade register and publication in the Official Monitor of Romania, Part IV.

In the case-law, in the matter, it was decided that the necessary quorum for the legal conduct of the extraordinary general meeting of the shareholders is distinguished from the quorum necessary for the legal adoption of the decision, more precisely the meeting of a certain majority of the voting rights held by the present or represented shareholders. The agenda mentioned in the convening notice determines the competence of the general assembly, not being able to take a decision on other issues than those inserted in the published agenda. This happens as the explicit mention in the convening notice of the issues that are the object of the agenda are done in order to inform the shareholders and give them the possibility to prepare their decisions, by knowingly exercising their right to vote. However, the material error, not caused by the fault of the company's representatives, considering the correct indication of the text of the law in the convening notice, cannot lead the conclusion of not ensuring the shareholders' right to information on the existing issues on the agenda of the general meeting, especially as this point from the agenda was detailed, once again, by the phrase regarding the compensation, not being able to lead, therefore, to the application of the sanction of the absolute nullity of the decision adopted by the general assembly.

The exercise of the attribution aiming at the increase of the legal capital, by the sole administrator, may be delegated to the board of directors or the directorate, by decision of the extraordinary general meeting of shareholders. As such, the delegate may increase the subscribed legal capital by issuing new shares, in exchange for contributions, but only in the case of strict interpretation which involves a limit of the determined nominal value - the authorized capital, which may not exceed half of the subscribed capital existing at the time of authorization, and only in a certain period of time, which may not exceed 5 years from the date of the company's registration (Bodu, 2017, p. 1100).

In conclusion, as seen, the legal capital can be increased in two ways, each involving different procedures. In this regard, a method of increasing the legal capital is represented by the increase without new contributions, therefore by using the company's internal resources, respectively through self-financing. A second method is to increase the legal capital by bringing new contributions and it can be achieved in two ways, respectively by issuing new shares or by increasing the nominal value of the existing ones.

As shown above, in the case of increasing the legal capital through new contributions, they will enrich the company's patrimony with certain patrimonial values, while in case of increasing the capital without new contributions, this effect is missing, the increase consisting of simple accounting operations. 


\section{References}

Bodu, S. (2017). Legea societăților comentată și adnotată, Bucharest, Rosetti Publishing House.

Cărpenaru, S.D. (2012). Tratat de drept comercial român conform noului cod civil, Bucharest, Universul Juridic Publishing House.

Chirieac, R. (2020). VAT enforcement by the Romanian tax authorities in the context of the uniform imposition of VAT in the European Union, Perspectives of Law and Public Administration, September 2020, 16-26.

PICBE |

Decision no. 425/17 ${ }^{\text {th }}$ of January 2014, Court of Appeal Târgu Mureș, Department II civil, administrative and fiscal.

Dumitru, O.I., Stoican, A. (2019). Drept comercial român, Bucharest, C.H. Beck Publishing House.

Law no. 31/1990 on companies.

Lupulescu, A.M. (2016). Some aspects concerning the setting up of companies regulated by the Law no. 31/1990 republished, Contemporary Challenges in the Business Law, ADJURIS, 123-132.

Nemeș, V. (2018). Drept Comercial. Ediția a-3-a revizuită și adăugită, Bucharest, Hamangiu Publishing House.

Piperea, G. (2020). Drept comercial român. Teoria generală, întreprinderea și insolvența, Bucharest, C.H. Beck Publishing House.

Tănăsică, O. (2017). Majorarea capitalului social al societăților destinate activității comerciale cu participare străină, Revista Universul Juridic, 6, 40-50. 